\title{
EARTHQUAKE LEARNING MEDIA DEVELOPMENT FOR DISASTER RISK REDUCTION
}

\author{
Dwi Partini ${ }^{1}$, Seli Umi Silaratubun ${ }^{2}$, Nurlaila Tuanany ${ }^{3}$ \\ 1,2,3 Geography Education, FKIP, Universitas Pattimura \\ Email: dwi.partini@fkip.unpatti.ac.id
}

\begin{abstract}
Indonesia is a country traversed by the Pacific ring of fire and is also the meeting point for tectonic plates, making it prone to various disasters including earthquakes. Many victims who fell during the earthquake disaster were due to a lack of understanding of the community in dealing with the disaster. An understanding of the community regarding earthquake disasters is needed to reduce the risk of earthquake disasters, one of which is done for students. Efforts to reduce earthquake risk can be done by developing earthquake learning media and applying it to students. The development of this learning media uses the 4D Model. The results showed that the use of earthquake learning media was effective in increasing students' understanding in dealing with earthquake disasters, so that this could unravel the risk of earthquake disasters for students.
\end{abstract}

Keywords: Earthquake; Disaster Risk; Learning Media

\section{A. INTRODUCTION}

Indonesia is a country that is prone to various disasters, both geological and hydrometeorological disasters. From a geological perspective, Indonesia is the meeting point of 3 technically active plates, namely the Eurasian Plate, the Pacific Plate and the Indoaustralian Plate. In addition, Indonesia is also crossed by the Pacific Ring of Fire, Indonesia has around 127 active volcanoes. This condition makes Indonesia vulnerable to geological disasters such as earthquakes, tsunamis and volcanic eruptions. Meanwhile, other hydrometeorological disasters such as floods and landslides occur because of the location of Indonesia which is in a tropical area with a high volume of rainfall. In addition, several regions in Indonesia have also been hit by drought and forest fires.

Based on 2019 data, the National Disaster Management Agency (BNPB, 2019) recorded 3,721 disaster events that occurred in Indonesia, consisting of tornadoes (1339), forest and land fires (746), floods (757), landslides (702), drought ( 123), earthquakes (29), tidal waves and abrasions (18), volcanic eruptions (7). The impact of the disaster during 2019 recorded 478 people died, 111 people were missing, 3,422 people were injured, and 6.1 million people suffered and were displaced. Physical 
damage due to the disaster included 73,726 damaged houses, of which 15,813 were heavily damaged, 14,566 were moderately damaged, and 43,347 were slightly damaged. 2,024 damaged facilities, including 1,123 educational facilities, 688 religious facilities, 213 health facilities (BNPB, 2019).

Especially for the Maluku region, throughout 2019, there were 5,089 earthquakes with various magnitudes and depths. This seismic activity has increased significantly compared to 2018 which was only 1,587 times. The earthquakes that occurred throughout 2019 were dominated by small earthquakes with a strength of less than 5.0 magnitude, which occurred 5,002 times, while significant earthquakes with magnitudes above M 5.0 occurred 87 times. Judging from the depth of the earthquake, the earthquake was dominated by shallow depth of less than $60 \mathrm{~km}$ as many as 4,641 times, medium depth and deep depth of more than 60 $\mathrm{km}$ as many as 448 times. As for the total 5089 earthquakes recorded, around 461 earthquakes were felt by the community. (Rusdin, 2019). The impact of the Maluku earthquake that occurred throughout 2019 was in the form of physical damage to 534 houses, 12 units of houses of worship, 8 government offices, and 6 damaged educational facilities. In addition, one health facility, one market facility, and one bridge were also damaged. As for the death toll of approximately 20 people died, 25 thousand people were displaced (CNNIndoensia, 2019).

The disaster management paradigm has shifted from emergency response management to risk management, with a shift in focus from post-disaster to predisaster since the World Conference on Disaster Reduction 18-22 January 2005 in Kobe, Hyogo, Japan (ISDR, 2005). Furthermore, (Weichselgartner \& Pigeon, 2015) states that the Sendai Framework for Disaster Risk Reduction 2015-2030 (UNISDR, 2015) has explained that one of the priority programs is to increase understanding of disaster risk. The application of this paradigm shift is by designing disaster risk reduction programs, one of which includes disaster education in official government programs. The shift in the disaster management paradigm from emergencies to risk management with a clear focus from the post-disaster to the pre-disaster stage has also contributed to the increasing number of educated professionals at the minimal level to understand the relationship between various disciplines regarding disaster risk reduction (Muryani et al., 2018). There are two aspects that have an 
important role in improving the resilience of vulnerable communities to natural disasters are education and communication (Paton et al., 2008). Education is a key mechanism through which children can participate in disaster risk reduction (Amri, 2015). Education has always been one of the priorities in the global commitment for DRR, as articulated in the Yokohama Strategy (United Nations, 1994), the Hyogo Framework for Action (HFA) 20052015 (ISDR, 2005). DRR activities involve learning, because they aim to change people's behaviour, perception and emotion (Kitagawa et al., 2017; Preston, 2012). Given the Sendai Framework for DRR 2015-2030 places "education as a crosscutting issue" (Shaw et al., 2011).

Starting from 2009, the Indonesian government has piloted a disaster risk reduction schools project originally named "disasterprepared schools" (or Sekolah Siaga Bencana in Indonesian) but now called "disaster-safe schools" (or Sekolah Aman Bencana in Indonesian). According to a government report from 2013, there are more than 25000 schools that have implemented the disaster-safe schools programme supported by government agencies and/or NGOs (Amri et al., 2017). In the curriculum of 2013 for senior high school, learning disaster is inserted into one of the Basic Competencies at Geography subjects. The development of disaster risk reduction skills among children and adults is one of the most urgent challenges of modern society. Schools can play an important role in disaster risk reduction because they often are important centers of community life. Therefore, schools directly impact not only the lives of teachers, students, parents and their relatives, but also the community as a whole. The majority of children spend most of their time at school and the school environment can determine their future destiny (UNICEF, 2012).

The curriculum is one of the strategic tools in an educational program that is strategic because the curriculum has a direct influence on the success of achieving educational goals. The curriculum serves as a guideline for selecting and preparing materials / materials, learning strategies, learning resources, media, and tools. (Sejati et al., 2019). There are a range of different approaches to integrating disaster risk reduction in the curriculum, each with its own merits and each with its own downsides. The approach strategy is the textbook-driven approach, the pilot project approach, the centralized competency-based approach, the 
centrally developed special subject (dedicated space) approach, the symbiosis approach and the special event approach (Selby \& Kagawa, 2012). The approach often used in Indonesia is the textbook-driven approach. One form of this approach is to design disaster risk reduction learning materials in learning media.

World-wide research has shown thatusing constructivism and multimedia technology are becoming increasingly important in teaching and learning in higher education in order to promote and enhance the teaching and learning process (Neo et al., 2007) when set within authentic contexts (Herrington et al., 2004). This enables teachers to better transfer knowledge to their students in the classrooms (Luan et al., 2003). This study aims to determine whether the use of earthquake disaster learning media can increase students' knowledge of earthquake disasters, and ultimately play a role in earthquake risk reduction efforts.

\section{B. MATERIALS AND METHODS}

This research succeeded in developing earthquake learning media. The product was developed using the 4D Model and has been validated by media experts and material experts. Learning media are equipped with pictures, maps, videos and supporting animations to make it easier for students to understand earthquakes starting from the basic theory of earthquakes, earthquake predisaster mitigation, mitigation during earthquake disasters and postearthquake mitigation. The stage currently being carried out by the researcher is the testing stage where the learning media is applied in the classroom to determine the effectiveness of earthquake disaster learning media in increasing students' understanding and preparedness for earthquake disasters. The experimental school was chosen where students had experienced an earthquake, namely SMA Negeri 2 Tulehu. The research method used to determine the effectiveness of the earthquake learning media developed was to provide a pretest before applying earthquake learning media to students and post-test after the application of earthquake disaster learning media. At the end of the lesson, students were also given a questionnaire to find out their responses to the use of learning media.

\section{RESULTS AND DISCUSSION}

1. Product Development

This research succeeded in developing earthquake learning media. The product developed using the 4D model, the 4D model, 
consists of 4 main stages, namely Define, Design, Develop and Disseminate. Learning media are arranged in the following order: apperception (general description of why Indonesia is often hit by earthquake disasters), factors causing earthquake disasters (theory with supporting photos or videos), the process of earthquake disasters, disaster impacts (explained using maps, pictures or videos), earthquake disaster mitigation which consists of pre-earthquake mitigation, during an earthquake and after an earthquake (theory with photo or video examples), closure (earthquake risk reduction appeal). It is in line with the opinion of (Crichton \& Kopp, 2006) that learning must be an integrated medium between text, graphics, video, animation and sound). The advantages of this learning media are the descriptions that use simple terms and language, complete with photos and videos to support the explanation of the material. The learning media has received validation from material experts and media experts with an 'excelent' value.

2. Student Response About The Use of Earthquake Disaster Learning Multimedia

Student responses regarding the use of earthquake disaster learning media can be seen in the following table.

Table 1. Student's Response (in percent)

\begin{tabular}{llllll}
\hline No & \multicolumn{1}{c}{ Students Response } & SA & A & LA & DA \\
\hline & earthquake disaster learning media can: & & & & \\
\hline 1. & Clearlyshow the process of earthquake disaster & 80 & 20 & 0 & 0 \\
\hline 2. & Make learning process more interesting & 82 & 18 & 0 & 0 \\
\hline 3. & $\begin{array}{l}\text { Cause students to give no attention toward the } \\
\text { lesson }\end{array}$ & 0 & 0 & 16 & 84 \\
& & & & & \\
\hline 4. & Make learning more fun & 87 & 10 & 3 & 0 \\
\hline 5. & Make students more focused & 84 & 12 & 4 & 0 \\
\hline 6. & Understand the impact of eartquake disasters & 92 & 8 & 0 & 0 \\
\hline 7. & Disturbing student concentration & 0 & 0 & 11 & 89 \\
\hline 8. & Allows students to be more active & 77 & 13 & 10 & 0 \\
\hline 9. & Make students more critical & 83 & 14 & 3 & 10 \\
\hline 10. & Make the material easier to remember & 80 & 20 & 0 & 0 \\
\hline
\end{tabular}

Notes: $\mathrm{SA}=$ Strongly Agree; $\mathrm{A}=$ Agree; $\mathrm{LA}=$ Less Agree; $\mathrm{DA}=$ Disagree 
The table above shows that in general students have a positive response to the use of earthquake disaster learning media, among others, because it is easier to understand the material, which causes students to be more creative, learn more fun, not boring students more concentration, easily understand the material and so on. learning media can make the learning experience more meaningful. This becomes an important thing in learning because it provides alternative choices for students with student-centered learning. Learning attitudes change when students realize that learning with learning media is more flexible in exploring and constructing new knowledge. This has engaged students and increased their interest in learning in this student-centered environment (Leow \& Neo, 2014). Students can navigate to sources of information in less time, build relationships between relevant topics, and build their knowledge by associating with meaningful ones.

3. The Effectiveness of Earthquake Disaster Learning Media to Improve Students' Knowledge and Understanding

Based on the results of the pretest-posttest, the average score of students in learning using earthquake disaster learning media was $20 \%$. The results of the increase in pretest and posttest scores can be seen in the following table and graph.

Table 2. Comparison of Pretest-Postes Value in Learning With Eartquake Disaster Learning Media

\begin{tabular}{cccc}
\hline No & Tes & \multicolumn{2}{c}{ Earthquake disaster learning media } \\
\cline { 3 - 4 } & & Total & Average \\
\hline 1 & Pretest & 2025 & 67.50 \\
\hline 2 & Posttest & 2430 & 81.00 \\
\hline 3 & Difference & 405 & 13.50 \\
\hline 4 & \% increase & & 20 \\
\end{tabular}

Source: Research Data 2020 


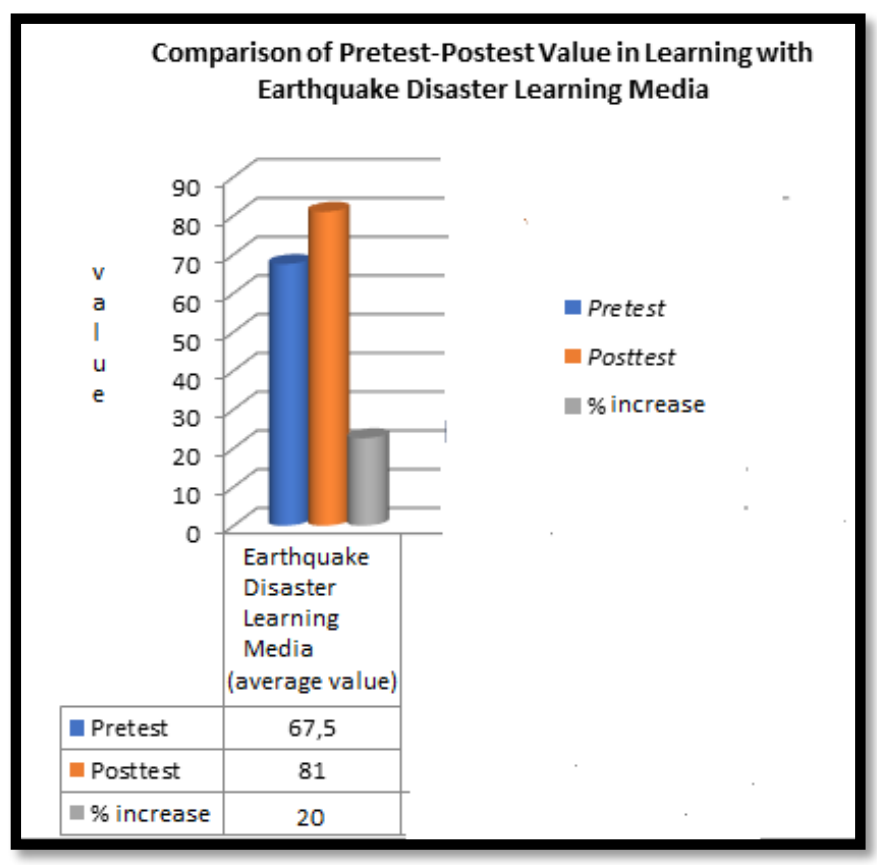

Figure 1. Graph Comparison of Pretest and Posttest Values in The Use of Earthquake Learning Media

The results of the pretest and posttest showed that students became more aware of earthquake disasters, their causes, impacts and mitigation. Mitigation means pre-earthquake mitigation, mitigation during an earthquake and mitigation after an earthquake occurs. Thus the students' knowledge increases and it is hoped that they already know what to do if at any time another earthquake occurs.

Based on the 2013 Curriculum, the knowledge of disaster risk reduction can be integrated in the lesson content, such as in the content of lessons such as science, language, and art (Abdul Qayyum \& Samar, 2014). In this study, knowledge about disaster risk reduction is integrated into geography learning.
Earthquake disaster materials and earthquake disaster mitigation are packaged in learning media in the form of instructional videos. Based on the explanation of the research results above, it is quite clear that with the prepared earthquake disaster learning media it can increase students' understanding of earthquake disasters and their mitigation. Understanding of earthquake disasters can reduce the risk of earthquake disasters, students become more aware of what they should do if this happens.

\section{CONCLUSIONS}

This research succeeded in developing earthquake learning media. The advantages of this learning media 
are descriptions that use simple terms and easy to understand language, equipped with photos and videos that support the explanation of the material. Most students have a positive response to the earthquake learning media which states that learning becomes more interesting and increases the clarity of the material. The use of earthquake learning media is effective in increasing students' understanding of earthquake disasters and earthquake disaster mitigation

\section{E. ACKNOWLEDGMENTS}

The research team would like to thank and praise FKIP Pattimura University for providing support in this research through the 2020 Faculty grant.

\section{F. REFERENCES}

Amri, A. (2015). Challenges in Implementing Disaster Risk Reduction Education: Views from the frontline in Indonesia. Challenges in Implementing Disaster Risk Reduction Education: Views from the Frontline in Indonesia Avianto, April, 111. https://www.researchonline.mq.ed u.au/vital/access/manager/Reposito ry/mq:44186

Amri, A., Bird, D. K., Ronan, K., Haynes, K., \& Towers, B. (2017). Disaster risk reduction education in Indonesia: Challenges and recommendations for scaling up. Natural Hazards and Earth System Sciences, 17(4), 595-612. https://doi.org/10.5194/nhess-17-
595-2017

BNPB. (2019). Kejadian Bencana Tahun 2019. BNPB. https://bnpb.go.id/infografis/kejadi an-bencana-tahun-2019

CNNIndoensia. (2019, December 28). Dampak Gempa Ambon: 20 Orang Meninggal, 25 Ribu Mengungsi. CNN Indonesia. https://www.cnnindonesia.com/nas ional/20190928174213-20-

435001/dampak-gempa-ambon-20orang-meninggal-25-ribumengungsi

Crichton, S., \& Kopp, G. (2006). Multimedia Technologies, Multiple Intelligences, and Teacher Professional Development in an International Education Project. Innovate: Journal of Online Education, 2(3). http://search.ebscohost.com/login.a spx?direct $=$ true $\& \mathrm{db}=$ eric $\& A N=E J$ $854488 \&$ lang $=$ pt-br\&site $=$ edslive \&scope=site\%5Cnhttp://www.i nnovateonline.info/index.php?view $=\operatorname{article} \& \mathrm{id}=39$

Herrington, J., Reeves, T. C., Oliver, R., \& Woo, Y. (2004). Designing authentic activities in web-based courses. Journal of Computing in Higher Education, 16(1), 3-29. https://doi.org/10.1007/BF0296028 0

ISDR. (2005). Hyogo Framework for Action 2005-2015. In ISDR (Issue January 2005). ISDR. https://doi.org/10.1007/978-14020-4399-4_180

Kitagawa, K., Preston, J., \& Chadderton, C. (2017). Preparing for disaster: a comparative analysis of education for critical infrastructure collapse. Journal of Risk Research, 20(11), 1450-1465.

https://doi.org/10.1080/13669877.2 016.1178661

Leow, F. T., \& Neo, M. (2014). Interactive multimedia learning: 
Innovating classroom education in a Malaysian university. Turkish Online Journal of Educational Technology, 13(2), 99-110.

Luan, W. S., Bakar, K. A., \& Hong, T. S. (2003). Differences in Anxiety between IT Competent and Incompetent Malaysian Pre-Service Teachers: Can a Discrete IT Course Taught in a Constructivist Learning Environment Solve This Problem? Turkish Online Journal of Educational Technology - TOJET, 2(4), 21-26. http://search.ebscohost.com/login.a spx?direct $=$ true $\& d b=$ eric $\& A N=E J$ 1101938\&site $=$ ehost-live

Muryani, C., Yusup, Y., \& Prihadi, S. (2018). The Importance of Disaster Learning Multimedia To Enhance Studentsr Preparedness. 262(Ictte), 153-156.

https://doi.org/10.2991/ictte18.2018.26

Neo, M., Neo, T.-K., \& Tai, X.-L. (2007). A constructivist approach to learning an interactive multimedia course: Malaysian students' perspectives. Australasian Journal of Educational Technology, 23(4), 470-489.

https://doi.org/10.14742/ajet.1247

Paton, D., Smith, L., Daly, M., \& Johnston, D. (2008). Risk perception and volcanic hazard mitigation: Individual and social perspectives. Journal of Volcanology and Geothermal Research, 172(3-4), 179-188. https://doi.org/10.1016/j.jvolgeores .2007.12.026

Preston, J. (2012). Disaster Education Race, Equity and Pedagogy. Sense Publisher.

Rusdin, A. A. (2019, December 31). Sepanjang 2019, BMKG: 5.089 Gempa Bumi Guncang Maluku.
Maluku

Terkini.

https://www.malukuterkini.com/20

19/12/31/sepanjang-2019-bmkg-

5089-gempa-bumi-guncang-

maluku/

Sejati, P. M., Budiningsih, C. A., \& Pujianto. (2019). Multimedia in Disaster Risk Reduction. Journal of Physics: Conference Series, 1233(1). https://doi.org/10.1088/17426596/1233/1/012090

Selby, D., \& Kagawa, F. (2012). Disaster Risk Reduction in School Curricula: Case Studies from Thirty Countries. In United Nations Children Fund. United Nations Children Fund. http://www.unicef.org/education/fil es/DRRinCurriculaMapping30countriesFINAL.pdf

Shaw, R., Shiwaku, K., \& Takeuchi, Y. (2011). Disaster Education. Emerald Group Publishing Limited.

UNICEF. (2012). Teaching Disaster Risk Reduction with Interactive Methods. UNICEF. www.erra.pk/.../TEACHING DISASTER WITH INTERACTIVE MET...\%0A

UNISDR. (2015). Sendai Framework for DIsaster Risk Reduction 20152030. In UNISDR. UNISDR.

United Nations. (1994). Yokohama Stategy and Plan of Action for a Safer World. World Conference on Disaster Reduction (A/CONF.206/6), May 1994, 2327.

Weichselgartner, J., \& Pigeon, P. (2015). The Role of Knowledge in Disaster Risk Reduction. International Journal of Disaster Risk Science, 6(2), 107-116. https://doi.org/10.1007/s13753015-0052-7 